\title{
Diagnosis of Financial Strategies Developed in Solidarity Economy Companies
}

\author{
Isabel Mendoza ${ }^{\# 1}$, Raúl J. Martelo ${ }^{* 2}$, Diofanor Acevedo ${ }^{* 3}$ \\ \# Independent Public Accountant, Riohacha, La Guajira, Colombia \\ ${ }^{1}$ isamel7@yahoo.es \\ ${ }^{*}$ Faculty of Engineering, Faculty of Economics Sciences, University of Cartagena, \\ Cartagena, Bolívar, Colombia. \\ 2 rmartelog1@unicartagena.edu.co \\ 3diofanor3000@gmail.com
}

\begin{abstract}
The objective of the research was to analyze the financial strategies that have been developed in solidarity economy companies in Colombia. This consisted in the diagnosis of the state of the companies in the solidarity field and to verify the viability of the strategies applied in the financial area. As a population, 92 workers were taken from companies in La Guajira, to whom the questionnaire instrument was applied, which was subjected to validity and reliability tests by expert judgment and Cronbach's Alpha coefficient, respectively. The results obtained reflect weaknesses in the strategic planning and management process in favor of financial improvement of the study companies.
\end{abstract}

Keyword - Investment Processes, Financial Indicators, Cash Management, Financial Planning

\section{INTRODUCTION}

The organizations in search of financial sustainability adopt emerging behaviors that allow them to maintain the competitive level, due to the globalized nature of the current world, which produces constant changes in the market. For this, companies apply financial management mechanisms, which facilitate obtaining the necessary resources for their efficient implementation in the scope of their objectives [1]. The foregoing implies that they must focus efforts on maintaining a financial income rate for self-sustaining, however, there are non-profitmaking companies called solidarity economy companies, which offer support in providing employment, goods or services to communities and they share some surplus resources as support for social change [2].

This type of company works according to the contribution of the partners and has a social and solidarity finance, which is supported by collections for savings, subsidies and donations [3]. Bearing in mind the above, they can be considered vulnerable in the face of an imperfect market and asymmetric competition, as well as the lack of support regarding technical knowledge and administration [4]. Therefore, they must apply strategies to maintain or improve the productivity of the company, with the disadvantage that their resources and income are limited.

Improvement or sustainability strategies should be related to the company's objective, to achieve the expected results, as an example of strategies applied in particular cases is the study of [5] who made the inclusion of farmers in the biodiesel production cooperatives, in order to improve the process and help the inhabitants of rural areas of Brazil. On the other hand, [6] they studied the benefits of vertical coordination on Chinese dairy companies, to determine the advantages of adopting this technique in the economic and social sustainability of these cooperatives. In addition, in [7] they analyzed the experience of a research project in an Italian consumer cooperative, where they implemented sustainability accounting tools to strengthen the level of mutuality and increase the social and economic added value of the organization.

Solidarity economy companies must have strategies for sustainability and increase financial resources, so they must be present as a business policy, in order to mitigate the uncertainty generated by a market that changes with the integration of new technologies or trends of a fashion. However, sometimes these strategies do not provide the expected results, due to planning failures, insufficient resources and unqualified personnel, among other aspects related to the state of the organization. In addition, the assets of the companies depend on the partners, which limits the implementation of tools or services to correctly execute the strategies with the highest requirements.

Considering the aforementioned, the objective of the research is to analyze the financial strategies of solidarity economy companies in Colombia, in order to diagnose their status and verify the feasibility of them into companies. 


\section{Methodology}

The research was considered as quantitative, with a non-experimental, descriptive cross-sectional design. Not experimental because the study variables were not manipulated during the study [8]. Cross-sectional or transverse because it was performed at a certain time [9]. And descriptive because the researcher analyzes the events that occur and explains them [10].

\section{A. Research procedure}

The development of the study was carried out according to the model established in Figure 1, which reflects the stages to analyze the financial strategies of solidarity economy companies.

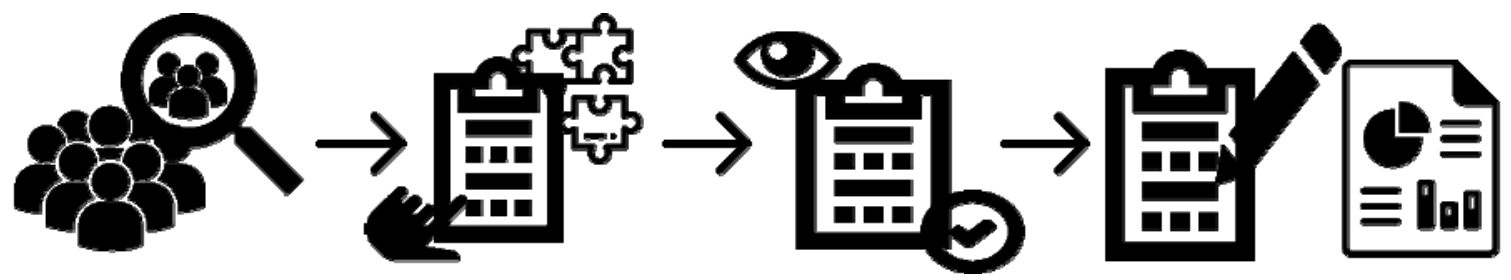

Fig. 1: Model for the analysis of financial strategies

1. Population and sample: The population consisted of 92 workers, of whom 20 works in the savings and credit cooperative of La Guajira-Confiamos LTDA, 22 in the social cooperative of La Guajira-Coopesagua LTDA and 50 workers of the multi-active cooperative of introducers and traders of hydrocarbons and their derivatives of the Indigenous and non-Indigenous of the Colombian-Venezuelan border Ayatawacoop in the Department of La Guajira, Colombia, for the year 2016. Regarding the sample, given that the population is small and accessible for research, it will not be necessary to sample, therefore the census was used [11].

2. Selection of technique and design of information gathering instrument: The survey was selected as a technique for collecting information due to the type of variables that are manipulated in the investigation. On the other hand, a questionnaire was designed, represented by a Likert-type opinion scale, with the purpose of describing the financial strategies developed in the companies of solidarity economy Fundecar (FEDEF), located in Riohacha, Colombia and the cooperative association Agroccidente in Maracaibo, Venezuela. The questionnaire was formed by 27 closed questions, consisting of five response alternatives classified as: (A) Always; (AA) Almost Always; (S) Sometimes; (AN) Almost Never and (N) Never.

3. Validity and Reliability of information gathering instruments: The questionnaire was subjected to a content validation test through expert judgment, in which five experts were chosen in the subject of study, who evaluated each item of the instrument to verify its clarity, congruence and relevance in relation to the objective, dimensions and indicators of the study variable. The suggestions and observations provided were considered to modify the questionnaire.

For reliability, the Alpha coefficient of Cronbach was implemented, where 10 workers with similar characteristics were selected to the subjects of the sample, who participated in the pilot test. For this, the Formula 1 was used.

$$
a=\frac{n}{n-1}\left(1-\frac{\sum S^{2} i}{S^{2} t}\right)
$$

Wherein:

$$
a=\text { Coefficient }
$$

$n=$ Number of items

$S_{i}^{2}=$ Variance of instrument items

$S_{t}^{2}=$ Variance of the total scores.

Then, with the solutions obtained from the Cronbach's Alpha coefficient, the level of correlation of the study variables was measured, using a scale (Table 1) that allowed categorizing them, for the interpretation of the results. 
TABLE I. Correlation index

\begin{tabular}{|c|c|}
\hline Interval & Correlation \\
\hline $0.81-1.00$ & Very High \\
\hline $0.61-0.80$ & High \\
\hline $0.41-0.60$ & Moderate \\
\hline $0.10-0.20$ & Very Low \\
\hline
\end{tabular}

4. Information gathering instruments application and Data analysis: the questionnaire was applied to the sample obtained in previous phases. The data obtained from the questionnaire were subjected to transformations according to a numerical scale $(1-5)$, where the values were distributed with the answer options as follows: (5) Always, (4) Almost Always, (3) Sometimes, (2) Almost Never, and (1) Never. Additionally, a scale was constructed (Table 2) that allowed us to interpret the information by means of descriptive statistics, according to the rank or interval to which it was positioned with respect to the responses of the respondents.

TABLE II. Scale for the statistical analysis of the mean

\begin{tabular}{|c|c|c|c|}
\hline Level & Interval & Category & Description \\
\hline 5 & $4.24-5.00$ & Very Favorable & $\begin{array}{r}\text { The variable that is being analyzed is located } \\
\text { within a very high frequency. }\end{array}$ \\
\hline 4 & $3.43-4.23$ & Favorable & $\begin{array}{r}\text { The variable that is being analyzed is located } \\
\text { within a high frequency. }\end{array}$ \\
\hline 3 & $2.62-3.42$ & Moderately Favorable & $\begin{array}{r}\text { The variable that is being analyzed is located } \\
\text { within a moderately high frequency. }\end{array}$ \\
\hline 1 & $1.81-2.61$ & Little Favorable & $\begin{array}{r}\text { The variable that is being analyzed is located } \\
\text { within a low frequency. }\end{array}$ \\
\hline
\end{tabular}

Then, the interpretation of the information was tabulated in tables, in order to facilitate the application of statistical calculations. The results were contrasted and the behavior of the indicators, dimensions and study variables was established, in order to analyze the financial strategies in greater detail and provide relevant results.

\section{III.RESULTS}

Next, the analysis and interpretation of the results obtained through the application of the information collection instrument to the 92 workers of solidarity economy companies is presented.

According to the study variable Financial Strategies, the dimensions were defined that allowed measuring their impact on companies. In addition, these dimensions were evaluated in relation to indicators, to provide a detailed analysis of the variable and its deployment. The definition of these characteristics is shown in Table 3.

TABLE III. Variable, Dimensions and Indicators of the investigation

\begin{tabular}{|l|c|c|}
\hline Variable & Dimension & Indicators \\
\hline \multirow{4}{*}{$\begin{array}{l}\text { Financial } \\
\text { Strategies }\end{array}$} & Types of Financial Strategies & Financial planning \\
\cline { 3 - 3 } & \multirow{3}{*}{ Process of investment } & Growth \\
\cline { 3 - 3 } & & Survival \\
\cline { 3 - 3 } & \multirow{3}{*}{ Short-term financial indicators } & Productivity \\
\cline { 3 - 3 } & & Optimize production lines \\
\cline { 3 - 3 } & & Working capital \\
\cline { 3 - 3 } & & Liquidity Solvency \\
\cline { 3 - 3 } & & Cash management \\
\hline
\end{tabular}

From the results of the questionnaire, the absolute frequencies and the percentages represented by each indicator were calculated with respect to the Types of financial strategies dimension, as shown in Table 4. 
TABLE IV. Dimension: Types of financial strategies

\begin{tabular}{|c|c|c|c|c|c|c|c|c|c|c|c|c|}
\hline \multirow{2}{*}{\begin{tabular}{|l|}
$\begin{array}{l}\text { Answer } \\
\text { categories }\end{array}$ \\
Indicators \\
\end{tabular}} & \multicolumn{2}{|c|}{$\begin{array}{l}\text { Always } \\
5\end{array}$} & \multicolumn{2}{|c|}{$\begin{array}{l}\text { Almost } \\
\text { Always } 4\end{array}$} & \multicolumn{2}{|c|}{$\begin{array}{l}\text { Sometimes } \\
3\end{array}$} & \multicolumn{2}{|c|}{$\begin{array}{l}\text { Almost } \\
\text { Never } 2\end{array}$} & \multicolumn{2}{|c|}{$\begin{array}{l}\text { Never } \\
1\end{array}$} & \multirow{2}{*}{$\begin{array}{l}\text { Weighted } \\
\text { Average }\end{array}$} & \multirow[t]{2}{*}{ Category } \\
\hline & af & $\%$ & af & $\%$ & af & $\%$ & af & $\%$ & af & $\%$ & & \\
\hline $\begin{array}{l}\text { Financial } \\
\text { planning }\end{array}$ & 3 & 3.26 & 5 & 5.43 & 60 & 65.22 & 24 & 26.09 & -- & -- & 2.85 & $\begin{array}{l}\text { Moderately } \\
\text { Favorable }\end{array}$ \\
\hline Growth & 5 & 5.43 & 15 & 16.30 & 32 & 34.78 & 40 & 43.48 & -- & -- & 2.83 & $\begin{array}{l}\text { Moderately } \\
\text { Favorable }\end{array}$ \\
\hline Survival & 3 & 3.26 & 5 & 5.43 & 30 & 32.61 & 54 & 58.70 & -- & -- & 2.53 & $\begin{array}{l}\text { Moderately } \\
\text { Favorable }\end{array}$ \\
\hline Averages & 4 & 3.98 & 8 & 9.05 & 41 & 44.20 & 39 & 42.76 & -- & -- & 2.74 & $\begin{array}{l}\text { Moderately } \\
\text { Favorable }\end{array}$ \\
\hline
\end{tabular}

There is evidence of a polarized average towards the answer alternative, Sometimes with $44.20 \%$ of the opinions issued by the subjects investigated, followed by a $42.76 \%$ for the option Almost Never, $9.05 \%$ in Almost Always, 3.98\% in Always, while the option Never obtained no value. The previous one produced a sum for the alternatives Sometimes and Almost Never of $86.96 \%$, nevertheless in the options Always and Almost Always a $13.03 \%$ was registered. As for the weighted average of this dimension, a value of 2.74 was obtained corresponding to the Moderately Favorable category, according to the scale used. Next, the indicators that make up this dimension were analyzed.

Regarding financial planning, it is evident that the highest percentage corresponded to the option Sometimes to $65.22 \%$, added to $26.09 \%$ registered in the Almost Never alternative, followed by Almost Always with $5.43 \%$ and Always with 3.26\%. These values correspond to a slightly favorable trend, due to the fact that the respondents pointed out that companies hardly apply financial planning to raise the level of operational efficiency, and increase the value and capacity to create wealth and well-being. Similarly, little efficiency strategies are developed to improve the cost structure or promote the inclusion of new products.

From the foregoing, it is important to point out that the results inherent to the financial planning indicator show divergence with what is based on [12], who point out that the most used strategy to achieve the objectives is an optimal financial planning, which focuses on three large axes or phases of formulation in which the plan is designed, put into action and in which future performance is compared with the plan.

In the Growth indicator, it is observed that $43.48 \%$ of the responses belong to the Almost Never alternative, which reflects that Colombian solidarity companies do not expand the market through the entry of their products into new markets and do not achieve higher sales in new clients, although a 34.78\% indicate doing it Sometimes, coupled with $16.30 \%$ in Almost always, and 5.43\% in Always. Taking into account these results and the weighted average of $2.83 \%$ obtained, it can be noted that there is a slightly favorable trend in the Growth indicator, when the company offers the market innovative products or services to obtain a greater participation in it.

In this sense, we can highlight the study carried out by [13] who mentions that the growth carried out by the companies represents the increase and development of the financial capacity and the operational volume to strengthen the quantity and quality of the products and services offered. Therefore, it is advisable to carry out strategies focused on the growth of solidarity economy companies that support their performance in the competitive environment.

On the other hand, it is demonstrated in the results of the Survival indicator they belong to a Medium Favorable tendency, because $58.70 \%$ of the answers were positioned in the alternative Almost Never, followed by Sometimes they are 32.61\%, Almost Always with $5.43 \%$ and Always with $3.26 \%$. The aforementioned evidences lack in the realization of reinforcement action strategies, to locate weaknesses that threaten the survival of the company, in addition, there are no actions when the existence of risk factors is diagnosed. Similarly, the weighted average of the indicator (2.53) indicates that there is a mildly moderate trend, which is why it is necessary to locate the weakness that endangers the survival of the organization.

In a particular case, [14] indicates that for survival or sustainability, the company must make changes that include the introduction of efficient technologies in the use of resources, sustainability reporting schemes and supply of sustainable products and services.

From a global perspective, the results linked to the "Types of financial strategies" dimension show a moderately favorable valuation, which leads to the conclusion that Colombian solidarity companies are not applying the strategies of financial planning, growth and survival, which brings as a consequence that the goals and objectives are not fully met. 
In this regard, [15] he points out that in order to solve some problems that exist in solidarity-based companies, the strategic aspect of the types of financial planning, growth and survival strategies must be ensured, given that their contribution to the formulation of a plan for To obtain a sustainable competitive advantage, procedures have been developed that complete the gaps left by budget planning, either short or long term.

Regarding the Investment Processes dimension, the answers issued by the respondents were grouped according to the indicators that constitute this dimension, as can be seen in Table 5.

TABLE V. Dimension: Investment Processes

\begin{tabular}{|c|c|c|c|c|c|c|c|c|c|c|c|c|}
\hline \multirow{2}{*}{$\begin{array}{l}\begin{array}{l}\text { Answer } \\
\text { categories }\end{array} \\
\text { Indicators } \\
\end{array}$} & \multicolumn{2}{|c|}{$\begin{array}{l}\text { Always } \\
5\end{array}$} & \multicolumn{2}{|c|}{$\begin{array}{l}\text { Almost } \\
\text { Always } 4\end{array}$} & \multicolumn{2}{|c|}{$\begin{array}{l}\text { Sometimes } \\
3\end{array}$} & \multicolumn{2}{|c|}{$\begin{array}{l}\text { Almost } \\
\text { Never } 2\end{array}$} & \multicolumn{2}{|c|}{$\begin{array}{l}\text { Never } \\
1\end{array}$} & \multirow{2}{*}{$\begin{array}{l}\text { Weighted } \\
\text { Average }\end{array}$} & \multirow[t]{2}{*}{ Category } \\
\hline & af & $\%$ & af & $\%$ & af & $\%$ & af & $\%$ & af & $\%$ & & \\
\hline Productivity & 21 & 22.83 & 24 & 15.22 & 40 & 43.48 & 17 & 18.47 & -- & -- & 3.42 & $\begin{array}{l}\text { Moderately } \\
\text { Favorable }\end{array}$ \\
\hline $\begin{array}{l}\text { Definition } \\
\text { of new } \\
\text { Products }\end{array}$ & 12 & 13.04 & 24 & 26.08 & 41 & 44.57 & 15 & 16.30 & -- & -- & 3.35 & $\begin{array}{l}\text { Moderately } \\
\text { Favorable }\end{array}$ \\
\hline $\begin{array}{l}\text { Optimize } \\
\text { production } \\
\text { lines }\end{array}$ & 18 & 19.57 & 12 & 13.04 & 50 & 54.35 & 12 & 13.04 & -- & -- & 3.39 & $\begin{array}{l}\text { Moderately } \\
\text { Favorable }\end{array}$ \\
\hline Averages & 17 & 18.48 & 16 & 18.11 & 44 & 47.47 & 15 & 15.94 & -- & -- & 3.38 & $\begin{array}{l}\text { Moderately } \\
\text { Favorable } \\
\end{array}$ \\
\hline
\end{tabular}

The above results indicate in the averages calculated, a percentage of $47.47 \%$ belonging to the alternative Sometimes, $18.48 \%$ in Always, $18.11 \%$ in Almost always and $15.94 \%$ in Almost Never, which implies a Medium-favorable trend, indicating that in Colombian solidarity companies moderately designed investment portfolios adapted to any investor profile and not invested in financial markets. In relation to the weighted average, a value of 3.38 was obtained corresponding to the category Medium favorable.

Relative to the indicators of the Investment Process Dimension, Productivity obtained an average of $43.48 \%$ in Sometimes, complemented by $22.83 \%$ in Always, $18.47 \%$ in Almost Never and $15.22 \%$ in Almost Always. According to the weighted average of this indicator of 3.42 corresponding to the Medium favored category, it is assumed that new products are moderately defined to offer investors. In addition, little is known about the rights enjoyed by investors when using these new products.

The analysis of the Optimize lines of production indicator, shows that $47.57 \%$ of the answers were concentrated on the option Sometimes, followed by $26.08 \%$ in Almost Always, $16.30 \%$ in Almost Never and $13.04 \%$ in Always, which indicates that the savings are used for the purchase of capital goods, capital goods or financial assets, in order to obtain from them an optimization in their production lines.

According to the results of the above indicator, it is inferred that when optimizing the production lines of products in Colombian solidarity companies, weaknesses are associated with having little knowledge regarding the risks of making a certain investment in the optimization of their lines of production, and do not tend to demonstrate innovations in their products or services. Taking into account these results and the value obtained in the weighted average (3.35), it is inferred that the indicator is Moderately Favorable.

Regarding the Investment Policies indicator, the results show that $54.35 \%$ of the opinions issued by the subjects surveyed agree that Colombian solidarity companies sometimes apply adequate investment policies to obtain better benefits, complemented by a $13.04 \%$ in Almost never, for a sum of $67.39 \%$. However, $32.61 \%$ distributed at $19.57 \%$ in Always and $13.04 \%$ in almost always consider that if they are being applied.

Consequently, it can be considered that the results obtained are not entirely consistent with what was pointed out by [16], who refer punctually to the need to be clear about the main aspects considered to establish the investment process in any type of company, which is why they emphasize aspects such as: productivity, definition and optimizing products, production lines and investment policies. These will allow the company to evaluate the scenarios to ensure assertiveness in making financial decisions and establish the strategies to follow.

Regarding the Short-term Financial Indicators dimension, the responses issued by the respondents were grouped according to the indicators that constitute this dimension, as can be seen in Table 6 . 
TABLE VI. Dimension: Short-term Financial Indicators

\begin{tabular}{|l|l|l|l|l|l|l|l|l|l|l|l|l|l|l|}
\hline $\begin{array}{l}\text { Answer } \\
\text { categories }\end{array}$ & \multicolumn{2}{l|}{$\begin{array}{l}\text { Always } \\
5\end{array}$} & \multicolumn{2}{l|}{$\begin{array}{l}\text { Almost } \\
\text { Always } 4\end{array}$} & \multicolumn{2}{l}{$\begin{array}{l}\text { Sometimes } \\
3\end{array}$} & \multicolumn{2}{l|}{$\begin{array}{l}\text { Almost } \\
\text { Never 2 }\end{array}$} & \multicolumn{2}{l}{$\begin{array}{l}\text { Never } \\
1\end{array}$} & \multicolumn{2}{l}{$\begin{array}{l}\text { Weighte } \\
\text { d } \\
\text { Average }\end{array}$} & Category \\
\hline Indicators & af & $\%$ & af & $\%$ & af & $\%$ & af & $\%$ & af & $\%$ & \\
\hline $\begin{array}{l}\text { Working } \\
\text { Capital }\end{array}$ & 12 & 13.04 & 20 & 21.74 & 44 & 47.83 & 16 & 17.39 & -- & -- & 3.30 & $\begin{array}{l}\text { Moderately } \\
\text { Favorable }\end{array}$ \\
\hline $\begin{array}{l}\text { Liquidity } \\
\text { Solvency }\end{array}$ & 18 & 19.57 & 15 & 16.30 & 47 & 51.09 & 12 & 13.04 & -- & -- & 3.42 & $\begin{array}{l}\text { Moderately } \\
\text { Favorable }\end{array}$ \\
\hline $\begin{array}{l}\text { Cash } \\
\text { Managemen } \\
\text { t }\end{array}$ & 14 & 15.22 & 12 & 13.04 & 50 & 54.35 & 16 & 17.39 & -- & -- & 3.26 & $\begin{array}{l}\text { Moderately } \\
\text { Favorable }\end{array}$ \\
\hline Average & 14 & 15.94 & 16 & 17.03 & 47 & 51.09 & 15 & 15.94 & -- & -- & 3.33 & $\begin{array}{l}\text { Moderately } \\
\text { Favorable }\end{array}$ \\
\hline
\end{tabular}

These data were located at an average of $51.09 \%$ in the alternative Sometimes, followed by $17.03 \%$ in Almost Always and 15.94\% equally in Always and Almost Never, these values are located in a Moderately Favorable trend indicative that Colombian solidarity companies moderately use short-term financial indicators to reach or approach optimal results by generating value for the company. Also, in this dimension we obtained a weighted average of (3.33), equally located in the moderately favorable category.

In reference to the capital work indicator, it is evident that $47.83 \%$ of the opinions were concentrated in the alternative Sometimes, followed by $21.74 \%$ in Almost Always, $17.39 \%$ in Almost Never and in smaller proportion a $13.04 \%$ Always. These results reflect a moderately favorable trend, given that the Colombian solidarity companies, moderately have the necessary capital for the production of goods, consumption and service provision, as well as little establish proposals with respect to their assets and liabilities in general. Regarding the weighted average, a value of (3.30) was obtained, corresponding to the Moderately Favorable category.

In this sense, reference is made to the issues raised by [17], who point out that working capital is a factor of production consisting of real estate, machinery or facilities of any kind, which, in collaboration with other factors, mainly work and intermediate goods, is intended for the production of consumer goods, services and knowledge among others, to distinguish analytically from the company and management.

Likewise, in the Liquidity - Solvency indicator, it is evident that $51.09 \%$ of the respondents indicate that the Colombian solidarity companies sometimes use the assets of the company in carrying out the commercial operations for the cancellation of the contracted obligations. That has adopted in relation to working capital, as well as select and measure the ability to cover short-term commitments, complements this statement by $19.57 \%$ Always positioned, $16.30 \%$ Almost Always and 13.04\% in Almost Never. The analysis of these results allows us to consider that the companies under study use and measure the capacity of the company to cover short-term commitments, excluding inventories (without selling them), as well as exercising control over cash, inventories and accounts receivable and the level of short-term debt. The weighted average of this indicator obtained a value of (3.42) located in the Moderately Favorable category, which evidences the moderate use of this financing strategy in Colombian solidarity companies.

The analysis corresponding to the results of the Cash Management indicator shows that $54.35 \%$ of the opinions agree that the managers of Colombian solidarity companies sometimes use the cash budget to comply with cash management, as well as they also emphasize the policies that must be followed with the conditioning factors of the company's liquidity, however, $17.39 \%$ consider that they almost never do it, despite $15.22 \%$ in always and $13.04 \%$ in They almost always claim that if this strategy is used.

In these results, the persistence of the moderately favorable trend is visualized, which is indicative that the managers of the Colombian solidarity companies studied, moderately maintain an efficient cash management, through the strategies adopted in relation to the accounts receivables, inventories and payments, which helps maintain the liquidity of the company. These are corroborated with the weighted average obtained from (3.26), equally located in the Moderately Favorable category.

In relation to the cash management indicator, [18] he points out that opinions about the company's cash are largely a result of the aspects with respect to the strategy on working capital of the companies, it is usually emphasized in the policies that must be followed by the conditioning factors of the company's liquidity, namely inventories, collections and payments.

Considering the results related to the Short-term Financial Indicators dimension, in its indicators: working capital, liquidity -solvency and cash management, it can be concluded that the management of the managers regarding the application of these indicators reflects a moderately favorable trend, since little is evaluated, 
interpreted or some kind of financial planning is done, with the different items or items contained in them, taking into account the issues raised by [17], who indicate that the best known method, which provides accounting for business decision making in the company, is the analysis of financial statements.

In relation to the development of the variable Financial Strategies (Table 7), the results show a weighted average of (3.15), for Colombian solidarity companies, This is equivalent to a moderately favorable trend, evidencing that financial strategies are not being considered within the microenterprises participating in the study, in order to obtain the resources required to finance the operations of the same, so weaknesses are observed in the process of strategic planning and management of these companies.

TABLE VII. Summary of the Financial Strategies Variable

\begin{tabular}{|c|c|c|c|c|c|c|c|c|c|c|c|c|}
\hline \multirow[t]{2}{*}{ Dimensions } & \multicolumn{2}{|c|}{$\begin{array}{l}\text { Always } \\
5\end{array}$} & \multicolumn{2}{|c|}{$\begin{array}{l}\text { Almost } \\
\text { Always } 4\end{array}$} & \multicolumn{2}{|c|}{$\begin{array}{l}\text { Sometimes } \\
3\end{array}$} & \multicolumn{2}{|c|}{$\begin{array}{l}\text { Almost } \\
\text { Never } 2\end{array}$} & \multicolumn{2}{|c|}{$\begin{array}{l}\text { Never } \\
1\end{array}$} & \multirow{2}{*}{$\begin{array}{l}\text { Weighted } \\
\text { Average }\end{array}$} & \multirow[t]{2}{*}{ Category } \\
\hline & af & $\%$ & af & $\%$ & af & $\%$ & af & $\%$ & af & $\%$ & & \\
\hline $\begin{array}{l}\text { Types of } \\
\text { financial } \\
\text { strategies }\end{array}$ & 4 & 3.98 & 8 & 9.05 & 41 & 44.20 & 39 & 42.76 & -- & -- & 2.74 & $\begin{array}{l}\text { Moderately } \\
\text { Favorable }\end{array}$ \\
\hline $\begin{array}{l}\text { Investment } \\
\text { Processes }\end{array}$ & 17 & 18.48 & 16 & 18.11 & 44 & 47.47 & 15 & 15.94 & -- & -- & 3.38 & $\begin{array}{l}\text { Moderately } \\
\text { Favorable }\end{array}$ \\
\hline $\begin{array}{l}\text { Short-term } \\
\text { Financial } \\
\text { Indicators }\end{array}$ & 14 & 15.94 & 16 & 17.03 & 47 & 51.09 & 15 & 15.94 & -- & -- & 3.33 & $\begin{array}{l}\text { Moderately } \\
\text { Favorable }\end{array}$ \\
\hline Averages & 12 & 12.80 & 13 & 14.73 & 44 & 47.59 & 23 & 24.88 & -- & -- & 3.15 & $\begin{array}{l}\text { Moderately } \\
\text { Favorable }\end{array}$ \\
\hline
\end{tabular}

The results obtained are discrepancies with what was stated by [19], who points out that financial strategies refer to the action and effect of managing or managing a business efficiently, hence the management must carry out various diligence and procedures, which will lead to the achievement of a specific objective of the company, as is the return on investment.

\section{IV.CONCLUSION}

From the results of the variable, dimensions and indicators studied in this investigation, the following can be concluded:

There are weaknesses of the managers linked to the types of financial strategies such as financial planning, growth and supervision because they reflect a median application of them, which translates into a moderately favorable trend, since little is being developed based on effectiveness, as well as those that drive penetration in the market. In the same way, they do not expand the product line of the company in its current market to meet the needs of its members.

In addition, managers have weaknesses in their ability to assertively drive investment processes from productivity, definition, optimization in their production lines and investment policies. In this case, the results point out that the shares attributed to management do not allocate investment portfolios adapted to any investor profile, nor do they use financial instruments to trade with other investors.

On the other hand, managers do little to fulfill the company's purposes in terms of short-term financial indicators through working capital, solvency-liquidity and cash management, given that less current liabilities are available to maintain the strategy in relation to working capital, nor do they emphasize the policies that must be followed by the conditioning factors of the company's liquidity.

Taking into account the above, it is concluded that there is a deficiency in the use of financial strategies, through its dimensions: Types of financial strategies, investment processes and short-term financial indicators, due to the fact that alternatives are used to strengthen them, which does not allow compliance with the objectives of Colombian solidarity economy companies.

\section{REFERENCES}

[1] S. Savina, and I. Kuzmina-Merlino, "Improving Financial Management System for Multi-business Companies," Procedia - Social and Behavioral Sciences, vol. 210, pp. 136-145, 2015.

[2] E. Miller, Solidarity economy: Key concepts and issues, In Solidarity economy I: Building alternatives for people and planet, pp. 93100. Massachusetts: Center for Popular Economics Amherst, 2010.

[3] A. Artis, "Social and solidarity finance: A conceptual approach,” Research in International Business and Finance, vol. 39, part B, pp. 737-749, 2017.

[4] M. D. N. Moraes, B. Souza, I. Cavalcante, A. L. Leocadi, S. M. Dias, and P. Rebouças, "Clusters in the Solidarity Economy: the strategy of participating in networks of enterprises in Brazil,” CIRIEC-España, Revista de Economía Pública, Social y Cooperativa, no. 86, pp. 34-59, 2016. 
[5] S. L. Stattman, and A. P. Mol, "Social sustainability of Brazilian biodiesel: The role of agricultural cooperatives," Geoforum, vol. 54, pp. 282-294, 2014.

[6] Z. Zhong, C. Zhang, F. Jia and J. Bijman, "Vertical Coordination and Cooperative Member Benefits: Case Studies of Four Dairy Farmers’ Cooperatives in China,” Journal of Cleaner Production, vol. 20, pp. 2266-2277, 2017.

[7] M. Battaglia, L. Bianchi, M. Frey and E. Passetti, "Sustainability reporting and corporate identity: action research evidence in an Italian retailing cooperative,” Business Ethics: A European Review, vol. 24, no. 1, pp. 52-72, 2015

[8] R. Kumar, Research Methodology: a step-by-step guide for beginners. London: SAGE Publications Ltd., 2011.

[9] W. Trochim, and J. Dongelly, The Research Methods Knowledge Base, 3rd edition. Cincinnati, OH: Atomic Dog Publishing, 2006.

[10] E. Babbie, The Basics of Social Research, Fifth Edition. Belmont, CA: Wadsworth Cengage Learning, 2011.

[11] B. Beins, and M. McCarthy, Research Methods and Statistics. United States of America: Pearson education Inc., 2012.

[12] D. Emery, J. Finnerty and J. Stowe, Principles of Financial Management. Prentice Hall, 1997.

[13] P. Vardarlier, Y. Vural, Ö. Yildirim and B. Yilmaztürk, "Impacts of Growth Strategies on Human Resources Policies," ProcediaSocial and Behavioral Sciences, vol. 99, pp. 861-868, 2013.

[14] R. Lozano, "Are Companies Planning their Organizational Changes for Corporate Sustainability? An Analysis of Three Case Studies on Resistance to Change and their Strategies to Overcome it," Corporate Social Responsibility and Environmental Management, vol. 20, issue 5, pp. 275-295, 2013.

[15] J. M. Jarrillo, International Strategy. Beyond export. Mexico: Editorial McGraw-Hill, 1994

[16] U. Garay, and J. Llanos, Invest in the long term. Caracas: Ediciones IESA, 2007.

[17] R. B. Ekelund, and R. F. Hébert, A history of Economic theory \& Method, 6th edition. Illinois: Waveland Press, Inc., 2014.

[18] T. Montilla, Fundamentals of Administration. México: Editorial TRILLA, 2009.

[19] R. Tiffin, Executive Finance and Strategy: How to Understand and Use Financial information to set strategic goals, 1st edition. Great Britain: Koga Page, 2014.

\section{AUTHOR PROFILE}

Isabel Mendoza Loperena works as independent Public Accountant (Colombia). Mrs. Mendoza completed his magister from Rafael Belloso Chacin University (Venezuela).

Raul J. Martelo works as full-time professor at the University of Cartagena (Colombia). Mr. Martelo completed his magister from Industrial University of Santander (Colombia). Mr. Martelo completed his undergraduate in Systems Engineering at the Industrial University of Santander.

Diofanor Acevedo Correa works as full-time professor in the University of Cartagena (Colombia). Dr. Acevedo completed his doctorate from University of Valle (Cali-Colombia). Mr. Acevedo completed his undergraduate in Food Engineering and Pharmaceutical Chemistry at the University of Cartagena. 